\title{
Jacobson Muscle Relaxatation Technique (Jpmr) (20 Min)
}

\author{
Bushra Mushtaq ${ }^{1 *}$ and Ajaz Ahmad Khan² \\ ${ }^{1} P G$ Psychaitry Nursing Scholar, India \\ ${ }^{2}$ Lecturer Clinical Psychologist, Department of Psychiatry, India
}

Submission: May 21, 2018; Published: May 25, 2018

*Corresponding author: Bushra Mushtaq, PG Psychaitry Nursing Scholar, India, Email: bushra.mushtaq77@gmail.com

\section{Requirements of JPMR}

Conductive Environment: The setting for relaxation is quiet

and of distraction noises. The client Will be kept physically comfortable in a position (Table 1).

General Instruction (Before and During Muscle Relaxation Exercise): This instruction is kept simple and is easily understood by students exposed to jacobson's progressive muscle relaxation technique and gives them a clear picture of how to co-operate during the exercise regimen.

a. To sit on a chair as comfortably as possible. Keep your body loose light and free.

b. Be calm and comfortable.

c. Keep your eye closed.

d. Avoid stray thoughts.

e. Avoid extra movements of the body. f. During the part of the exercise cycle tense the muscle tightly and hold for slow count of 5 seconds. (Repeat silently $1001,1002,1003, \ldots)$

g. During the relation part of exercise cycle relaxes the muscle quickly and completely .let your mind relax and appreciate how relaxed the muscle is feeling for 10 seconds.

h. Try to keep all other muscles relaxed as you exercise specific muscle group.

i. As you exercise from head to toe.

Observe changes like tightness and the development of light and soothing sensations.

j. Relax by taking three deep breaths inhaling through nose and exhaling through mouth after each step.

k. Now make your body completely loose.............light.............. and free

l. Let us being your exercise.

Table 1

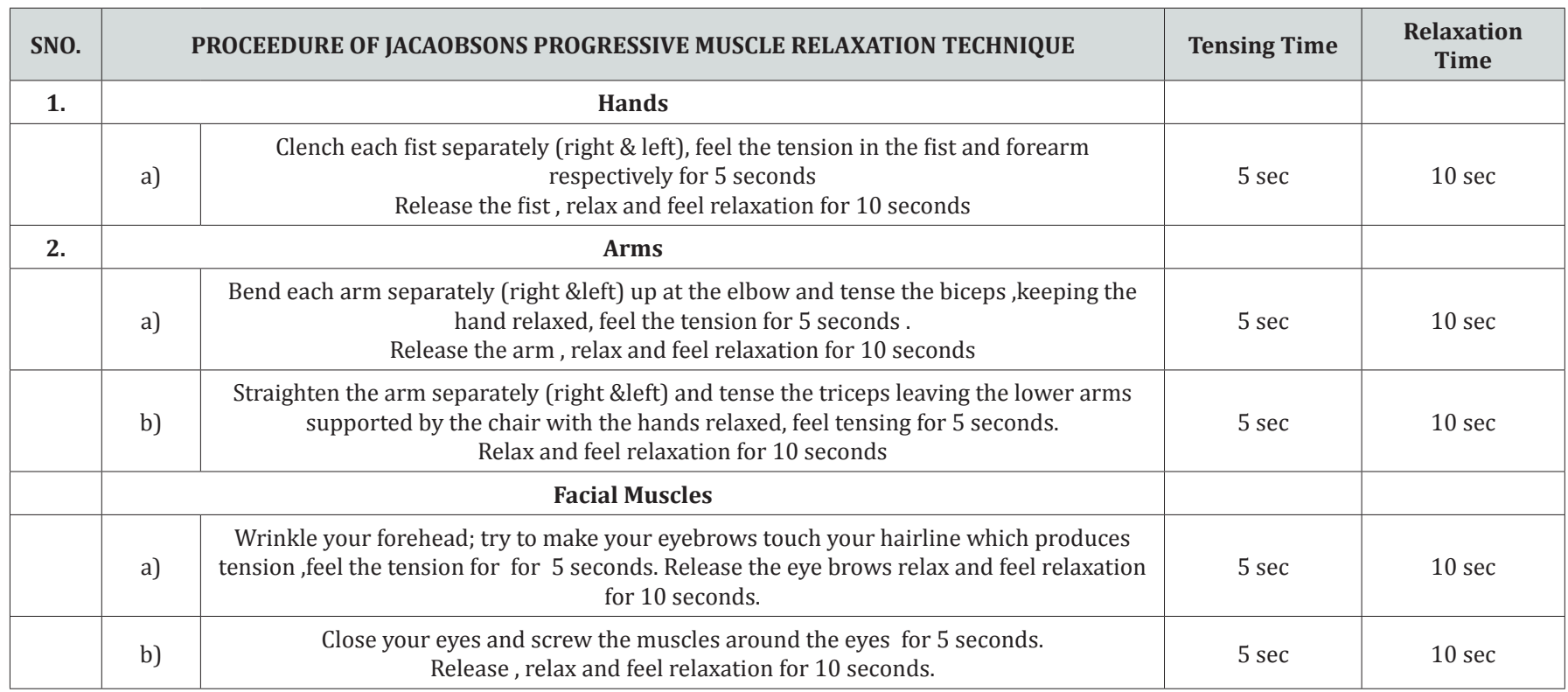




\begin{tabular}{|c|c|c|c|c|}
\hline & c) & $\begin{array}{l}\text { Tense the jaw by biting the teeth together, feel the tension in the jaw muscles for } 5 \\
\text { seconds. } \\
\text { Release, relax and feel relaxation for } 10 \text { seconds. }\end{array}$ & $5 \mathrm{sec}$ & $10 \mathrm{sec}$ \\
\hline & d) & $\begin{array}{l}\text { Press the tongue hard and flat against the roof of mouth with lips closed notice tension in } \\
\text { throat and feel it for } 5 \text { seconds. } \\
\text { Release, relax and feel relaxation for } 10 \text { seconds. }\end{array}$ & $5 \mathrm{sec}$ & $10 \mathrm{sec}$ \\
\hline \multirow[t]{4}{*}{3.} & \multicolumn{2}{|r|}{ Neck \& shoulder } & & \\
\hline & a) & $\begin{array}{l}\text { Push the head back as far as it will go (against a chair),feel the tension for } 5 \text { seconds. } \\
\text { Bring head to its position, relax and feel relaxation for } 10 \text { seconds. }\end{array}$ & $5 \mathrm{sec}$ & $10 \mathrm{sec}$ \\
\hline & b) & $\begin{array}{l}\text { Bring the head down and press the chin down on to the chest for } 5 \text { seconds. } \\
\text { Bring the head to its position, relax and feel relaxation for } 10 \text { seconds. }\end{array}$ & $5 \mathrm{sec}$ & $10 \mathrm{sec}$ \\
\hline & c) & $\begin{array}{l}\text { Tense shoulder by tightening and shrinking shoulders ( Shrug your shoulders up to your } \\
\text { ears ), feel the tension for } 5 \text { seconds. } \\
\text { Release, relax and feel relaxation for } 10 \text { seconds. }\end{array}$ & $5 \mathrm{sec}$ & $10 \mathrm{sec}$ \\
\hline \multirow[t]{2}{*}{4.} & \multicolumn{2}{|r|}{ Chest } & & \\
\hline & a) & $\begin{array}{c}\text { Take a deep breath, completely filling the lungs, hold the breath for few seconds and } \\
\text { passively exhale. } \\
\text { Relax and feel relaxation for } 10 \text { seconds. }\end{array}$ & $5 \mathrm{sec}$ & $10 \mathrm{sec}$ \\
\hline \multirow[t]{2}{*}{5.} & \multicolumn{2}{|r|}{ Stomach. } & & \\
\hline & a) & $\begin{array}{l}\text { Pull in the stomach and tense the stomach muscle for } 5 \text { seconds. } \\
\text { Release the stomach, relax and feel relaxation for } 10 \text { seconds }\end{array}$ & $5 \mathrm{sec}$ & $10 \mathrm{sec}$ \\
\hline \multirow[t]{2}{*}{6.} & \multicolumn{2}{|r|}{ Back } & & \\
\hline & a) & $\begin{array}{l}\text { Arch your back away from the chair feel tension for } 5 \text { seconds. } \\
\text { Relax and feel relaxation for } 10 \text { seconds. }\end{array}$ & $5 \mathrm{sec}$ & $10 \mathrm{sec}$ \\
\hline \multirow[t]{2}{*}{7.} & \multicolumn{2}{|r|}{ Thighs \& Buttocks } & & \\
\hline & a) & 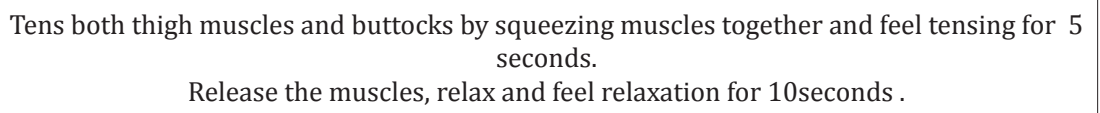 & $5 \mathrm{sec}$ & $10 \mathrm{sec}$ \\
\hline \multirow[t]{3}{*}{8.} & \multicolumn{2}{|r|}{ Lower Legs } & & \\
\hline & a) & $\begin{array}{l}\text { Point toes towards your head, producing tension in calf muscles, feel tensing for } 5 \text { seconds. } \\
\text { Relax and feel relaxation for } 10 \text { seconds. }\end{array}$ & $5 \mathrm{sec}$ & $10 \mathrm{sec}$ \\
\hline & b) & $\begin{array}{l}\text { Point the toes away from the head, feel the tension for } 5 \text { seconds. } \\
\text { Relax and feel relaxation for } 10 \text { seconds }\end{array}$ & $5 \mathrm{sec}$ & $10 \mathrm{sec}$ \\
\hline \multirow[t]{2}{*}{9.} & \multicolumn{2}{|r|}{ Toes } & & \\
\hline & & a) Relax and feel relaxation for 10 seconds. & $5 \mathrm{sec}$ & $10 \mathrm{sec}$ \\
\hline \multirow[t]{5}{*}{10.} & & After Exercises & & \\
\hline & a) & Relax whole body completely. & & \multirow{4}{*}{2 min relaxation } \\
\hline & b) & Keep your eyes closed and let yourself remain in the relax position. & & \\
\hline & c) & Open your eyes and enjoy renewed energy, feel relaxed and refreshed. & & \\
\hline & d) & sit up, stretch, and stand up slowly & & \\
\hline
\end{tabular}

\section{References}

1. Keith Hawton, Paul M Salkovskis, Joan Kirk, David M Clark (1989)

Cognitive Behaviuor Therapy for Psychiatric Problems. A Practical Guide, Oxford University Press, India, pp. 472. 
This work is licensed under Creative Commons Attribution 4.0 License

DOI: 10.19080/JOJNHC.2018.08.555726

\section{Your next submission with Juniper Publishers} will reach you the below assets

- Quality Editorial service

- Swift Peer Review

- Reprints availability

- E-prints Service

- Manuscript Podcast for convenient understanding

- Global attainment for your research

- Manuscript accessibility in different formats

(Pdf, E-pub, Full Text, Audio)

- Unceasing customer service

Track the below URL for one-step submission https://juniperpublishers.com/online-submission.php 